\title{
Smírčí řízení prováděné obecným soudem jako forma alternativního řešení sporů
}

\section{Judicial Settlement Proceedings in Civil Courts as a form of ADR}

\author{
Drahomíra Němcová*
}

\begin{abstract}
Abstrakt
Clánek se zabývá smirčim řżenim u civilnich soudu. Prezentuje tento typ ř̌zeni jako použitelnou formu alternativního rèseni sporu (ADR metoda).

$\checkmark$ prvni cásti se hovoř́ o bistorickém vývoji institutu a rĩzným prǒstupiom k soudnimu smíru. Zamèruje se dále na aktuálni problematické aspekty právni úpravy, napríkelad neexistenci stavení promlèeni prì zabájeni smirččbo rìzení.

Po implementaci EU smèrnice o mediaci v civilnich věcech müže smirč rözeni slouřit také k prétavení mediačni dohody do exekučního titulu. Práce se snaži prĭspèt ke diskusi, zda by měl soudce vést tento drub rǐzení, prestože je jeho primárni úlohou judikatorni činnost.

$V$ článku je komparováno české smirč̀ rìzeni spodobnou rakouskou úpravou. Ta obsahuje také formu povinnébo smiru, což by se mohlo stát inspiraci pro české právo.
\end{abstract}

\section{Klíčová slova}

ADR metody; soudni a prétorský smir; smirči ř̌zeni; promlěeni; mediačni dohoda; role soudce v civilním ř́zeni; rakouský právni systém; povinný pokus o smir.

\section{Abstract}

The article deals with a judicial settlement proceedings in civil courts. It presented this type of proceedings as a useful form of alternative dispute resolution method (ADR method).

Historical background is covered to show the development and different approaches to the judicial settlement. The paper also points at current problematic aspects of provisions dealing with judicial settlement proceedings, such as absence of limitation of time when instituting the proceedings.

Since the EU direction about mediation in civil and commercial cases has been implemented, proceedings can also serve for executing the mediation agreement. The article raises the question whether judge should bold such a proceedings, although his primary task is to adjudicate the cases.

Austrian legal system has similar provisions upon judicial settlement proceedings, thus the article contains comparison of these two systems of law. Austrian obligatory form of settlement could become an inspiration in Czech law.

\section{Keywords}

ADR Methods; Judicial Settlement; Judicial Settlement Proceedings; Limitation of Time; Mediation Agreement; Role of a Judge in Civil Proceedings; Austrian Legal System; Obligatory Settlement Proceedings.

\section{1 Úvod}

Smírčí řízení dle \ 67 a násl. zákona č. 99/1963 Sb., občanského soudního řádu (dále „OSŘ`), je v současnosti institutem opomíjeným jak právní teorií, tak právní praxí. Jeho

\footnotetext{
* Mgr. Drahomíra Němcová, doktorandka, Právnická fakulta, Univerzita Palackého v Olomouci / Ph.D. student, Faculty of Law, Palacký University, Olomouc, Czech Republic / E-mail: fridrichova.drahomira@email.cz
} 
právní úprava, dlouho existující v českém právním řádu, je promítnutím zásady smírného řešení sporů. Ta je v současném civilním procesu hojně diskutovaná a propagovaná. Je zvláštní, že ačkoliv má institut dlouho tradici, málokdy byl v historii podroben kritickému zkoumání. Slovy dnešní terminologie se jedná o alternativní metodu řešení sporu (zkratka „ADR“), nebot’ při ní nedochází k judikatorní činnosti soudu (autoritativnímu rozhodování o právech a povinnostech stran). Přesto se od jiných ADR metod podstatně liší: probíhá na půdě soudu, není tedy metodou „mimosoudni““.

Mezi ADR metodami se dnes na prvním místě zmiňuje mediace, kdy se za pomoci třetí osoby (mediátora) snaží strany sporu dospět k oboustranně přijatelné dohodě. Fakticky sdílí se smírčím řízením stejný účel, dosažení dohody (resp. smírného řešení sporu). Ačkoliv jsou mediace a postavení mediátora upraveny veřejným právem, mediátor není soudcem, je soukromou osobou. Vzájemné dohody mohou mezi sebou strany dosáhnout také u notáře formou notářského zápisu se svolením k vykonatelnosti. Do jaké míry si tyto metody konkurujî? Představují mediace a notářský zápis náležitou alternati$\mathrm{vu}-\mathrm{s}$ tím, že úprava smírčího řízení u civilních soudů ztrácí smysl?

Lze se setkat s hlasy odborné veřejnosti, které popisují smírčí řízení jako neaplikovatelný institut odsouzený k zániku. Pojem neaplikovatelnost však nelze zaměňovat s pojmem neaplikovanost. Smírčí rúizení skutečně není v praxi př́liš využíváno. Je dobré podívat se do jiného právního řádu, který obsahuje podobný institut, a zjistit, jakým způsobem se aplikuje tam. Pro komparaci je z těchto důvodů vhodná rakouská právní úprava.

\section{Smírčí řízení a jeho historický vývoj}

Smírčí rúizení je dnes upraveno v části druhé OSŘ, spolu s předběžnými řízeními. Ustanovení \ 67 OSŘ popisuje smírčí řízení jako ,pokus o smir “před zahájením sporu. Je tedy nutno vycházet z pojmu smír. Ten se liší od prosté hmotněprávní dohody právě tím, že jde o smlouvu uzavřenou "mezi spornými stranami pred soudem a za jeho spolupuisobení s úmyslem skoncovat jistý spor mezi nimi “.' Nebot’ je ho dosahováno u soudu, má charakter procesního úkonu. ${ }^{2}$

Z pohledu hmotného práva se však jedná skutečně o dohodu, v mnoha případech formou narovnání. ${ }^{3}$ Smír je proto označován za tzv. kvalifikovaný druh dohody, v němž se spojuje hmotné a procesní právo.

1 HORA, Václav. Učebnice civilního práva procesního. 1. vyd. Praha: Všehrd, 1947, s. 403.

2 Usnesení Nejvyššího soudu ze dne 27. 4. 2009, sp. zn. 22 Cdo 5170/2007. Nejvyšši soud [online]. Nejvyšší soud 2009 [cit. 12. 3. 2016]. Dostupné z: http://nsoud.cz/Judikatura/judikatura_ns.nsf/WebSearch/ AD91306493C1A706C1257A4E00695106?openDocument\&Highlight=0. Nejvyšší soud hovoří o tom, že „smír je procesni dohoda účastnikeï.

3 Může jít i o uznání závazku, vzdání se práva, dohodu o splátkách atd. - stanovisko Nejvyššího soudu ze dne 11. listopadu 1986, sp. zn. Cpj 44/86. V souvislosti s tímto stojí za zmínku německá terminologie: rakouský výraz pro smír a narovnání je totožný - der Vergleich. 
Smírčí rízení má v našem právu dlouho historii. První moderní úpravu smírčího řízení nalezneme už v roce $1781 \mathrm{v}$ Obecném soudním řádu. Poté smírčí řízení převzal Civilní řád soudní (zkráceně CŘS) z roku 18954, platný pro západní část Rakousko - Uherska. Upravoval ho v jediném paragrafu - \433 CǨS.

Dle tohoto ustanovení se pokus o smír konal před okresním soudem v nařízeném soudním roku. Pokud byl ohledně uzavřeného smíru sepsán protokol, smír se stával exekučním titulem. Jinak však nebyly smíru přiznány účinky pravomocného rozsudku, jeho účinky byly výlučně res transacta. Soud navíc neměl pravomoc, ani oprávnění smír jakkoliv schvalovat. Z této úpravy se do dnešních dnů zachovala jistá kusost, úspornost právní úpravy. V odborné literatuře se ani tehdy, ani dnes nemluví o důvodech minimální úpravy smírčího rrízení. Nabízejí se však dva závěry. První je založen na tezi, že se má stranám sporu poskytnout co největší volnost, bez svazování mnoha pravidly (zejména procesního charakteru). ${ }^{5}$ Druhý důvod je pragmatičtější: úprava se nevyužívá př́iliš často, v praxi proto nevyvstala potřeba upravit některé otázky podrobněji.

Velkou změnou $\mathrm{v}$ přístupu ke smírčímu řízení a smíru obecně naproti tomu je fakt, že schválený prétorský smír má podle dnešní právní úpravy účinky pravomocného rozsudku. K účinku res transacta tedy pristoupil také účinek res iudicata. Aby se smír stal res indicata, je nutné, aby jej soud schválil (resp. potvrdil). Soud rozhoduje o tom, zda je konkrétní podoba smíru v souladu s právem. ${ }^{7}$ Výhodou pro strany - oproti jiným ADR formám - je, že schválený smír představuje exekuční titul. ${ }^{8}$

\section{Právní úprava}

Jak bylo podáno výše, smírčí řízení je upraveno pouze minimálně. Klade se otázka, zda či do jaké míry se mohou v rámci smírčího řízení uplatnit zásady a pravidla sporného (prvostupňového) řízení.

Dle systematiky OSŘ patří smírčí řízení mezi předběžná řízení. ${ }^{9}$ Pokud je svou povahou skutečně předběžným řízením, pak se na něj jako na řízení upravené v části druhé

4 Zákon č. 113/1895 Sb.z.ř., civilní řád soudní.

5 MYSLIL, Stanislav. Málo smírů v majetkových sporech. Právní roz̧bledy. 2003, roč. 11, č. 11-12, s. 34. ISSN 12106410.

6 Pravidlo bylo zavedeno zákonem č. 99/1963 Sb., občanský soudní řád, a od té doby je účinné až do současnosti.

7 Schvalování smíru, stejně jako účinky smíru coby pravomocného rozsudku přineslo období socialismu. Smír a smírči řízení bylo socialistickým právem dosti propagované, protože šlo o projevy zásady kooperace všech jedinců. Viz MACUR, Josef. Zásada projednaci v civilním soudním ř́zení. 1. vyd., Brno: Masarykova univerzita, 1997, s. 120. Ve skutečnosti všechna zdůvodnění jen ,zastírala absolutizaci státní moci“. Viz Tamtéž, s. 73.

8 Mediační doložka není sama o sobě exekučním titulem!

9 Před přijetím zákona o zvláštních řízeních soudních bylo v předběžných řízeních upraveno smírčí řízení spolu s řízením o určení otcovství souhlasným prohlášením rodičů. Šlo spíše o důsledek novelizací, než záměr zákonodárce. 
„ustanoveni části treti občanskébo soudního rádu (...) vątahuji (...) jenom tehdy, jestliže to vyplývá z. ustanoveni drubé části (...), poprr. jestliže je to výslovně uvedeno v ustanoveni treti části občanskébo soudního rádu. "10, jak judikoval Nejvyšší soud.

\ 69 OSŘ obsahuje výslovný odkaz na aplikaci ustanovení \99 OSŘ. Charakter smírčího rrízení však vyvolává úvahy, zda nelze bez výslovného odkazu analogicky aplikovat i jiná ustanovení části třetí, resp. zásady sporného řízení.

Vzhledem k tomu, že je civilní proces řazen do veřejného práva, platí i zde obecné pravidlo o nepř́pustnosti užití analogie. Nicméně analogie není vyloučena absolutně. Existuje tu základní limit, „... analogii ve verejném právu nelze pouřît v neprospěch toho, kedo vykonavatelem verejné moci neni. " ${ }^{11} \mathrm{Na}$ druhou stranu je ,prirozenou a nezbytnou soućásti právnického usurování $v$ kterékoliv oblasti a v každém drubu ř́zeni" "12 Jistotou ale zůstává, že analogie je přípustná ve prospěch účastníků řízení. ${ }^{13}$

Současná praxe i judikatura např́iklad tvrdí, že pro smírčí řízení neplatí ustanovení \103 OŠ̌ o zkoumání podmínek řízení. Tento závěr však není zcela správný, protože mezi předpoklady ${ }^{14}$ smírčího řízení patři na prvém místě pravomoc soudu. Soud tak vždy musí aplikovat obecná pravidla \ 7 OSŘ.

Podle výše uvedeného závěru o užití analogie, bychom se museli ptát, zda je zkoumání podmínek ku prospěchu účastníka řízení, či nikoliv. Tvrzená neaplikovanost \103 OSŘ však dle mého názoru neplyne z toho, zda je či není na újmu účastníkủ, spíše vychází z charakteru smírčího řízení (rozhodovat může každý okresní soud - není třeba zkoumat věcnou př́islušnost; nezáleží na místní příslušnosti apod.).

Zvláštním předpokladem stanoveným prrímo v úpravě smírčího řízení je přípustná povaha věci. Uzavření smíru přichází v úvahu, když mohou účastníci upravit „dispoz̧itivními úkony mezi sebou právní pomèr " "Ty5. Typicky jde o spory na plnění povinnosti. Lze jim také určit, zda existuje právo či právní vztah ${ }^{16}$ nebo nahradit projev vưle. Mezi př́pady vyloučené z pokusu o smír naopak patř́ otázky osobního stavu (např̀. určení otcovstvî),

10 Rozhodnutí Nejvyššího soudu ze dne 30. června 1965, sp. zn. 5 Cz 31/66 (R 63/1966).

11 KINDL, Milan. Malá úvaha o analogii ve veřejném právu. Právník, 2003, roč. 142, č. 2, s. 133.

12 HAJN, P. Analogie jako právní institut a jako způsob usuzování. Několik poznámek k analogii v právu (nejen) správním. Právník, 2003, roč. 142, č. 2, s. 123.

13 Tamtéž.

14 STAVINOHOVÁ, Jaruška, HLAVSA, Petr. Civilníproces a organizace soudnictví. 1. vyd., Masarykova univerzita Brno: Doplněk, 2003, s. 252. ISBN 80-7239-155-0.

15 Nejvyššr soud o občanském soudním ř̈zeni v některých věcech pracouněprávnich, občanskoprávních a rodinnèprávnich: sbor-

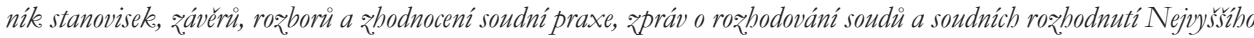
soudu 1964-1969. Praha: SEVT, 1980 (S III), s. 316: stanovisko Nejvyššího soudu, sp. zn. Cpj 168/64.

16 Např. určení vlastnického práva k nemovitosti: rozsudek Nejvyššího soudu ze dne 27. 3. 2013, sp. zn. 30 Cdo 626/2013. Nejyyššs soud [online]. Nejvyšší soud 2013 [cit. 30. 3. 2016]. Dostupné z: http://nsoud.cz/Judikatura/judikatura_ns.nsf/WebSearch/ C1E8D161325CB3CFC1257B4100329546?openDocument\&Highlight $=0$ 
věci, $\mathrm{v}$ nichž $\mathrm{k}$,vytvoření žádaného stavu je třeba soudního výroku, [i to], co nelze vyřešit dohodou" ${ }^{17}$

Výše uvedené vytváří mantinely pro konání smírčího řízení. Jinou otázkou ale je, která z prrípustných věcí se hodí pro uzavření smíru nejvíce. Smysl má pokus o smír zejména tam, kde se předpokládají déletrvající právní vztahy (obchodní18 ${ }^{18}$ partneři, pracovněprávní vztahy). Pro pracovněprávní vztahy, resp. jiné vztahy, kde figuruje slabší strana, se smírčí řízení jeví oproti jiným ADR metodám řešení sporu jako nejvhodnější možnost, a to z důvodu postavení soudu coby orgánu státní moci. Zajímavé výsledky by mohlo smírčí řízení zaznamenat i v ochraně osobnosti či hospodářské soutěži. ${ }^{19}$

\section{Průběh smírčího řízení}

Smírčí řízení je řízením výlučně návrhovým. Návrh je podle závěrů judikatury ${ }^{20}$ pouhým podáním ve smyslu \42 OSŘ odst. 4. I když není žalobou, někdy se v odborné literatuře požaduje přesná formulace petitu ${ }^{21}$. Tento př́stup je příkladem nepřípustné analogie (v neprospěch účastníků), nenajdeme pro něj žádnou oporu v právní úpravě. Ignoruje navíc fakt, že návrh nemusí směřovat ke schválení konkrétní podoby (zněnî) smíru. Může naopak jít jen o vybídnutí druhé strany k účasti na „pokusu o smír“.

$\mathrm{S}$ podáním návrhu nejsou spojeny žádné z účinků podání žaloby. ${ }^{22}$ Nepůsobí ani litispendenci, ani stavení promlčecí lhůty. Nedostatek účinků podání žaloby je jedním z důvodů, proč není smírčí ř́zení pro strany sporu atraktivním právním nástrojem. I když mají vůli dohodnout se, nemají jistotu, že mezitím (jedné či druhé) neuplyne promlčecí doba.

Dle zákona č. 40/1964 Sb., občanský zákoník (dále OZ) ${ }^{23}$ nemělo podání návrhu ani samotné smírčí řízení vliv na běh promlčecích lhưt ${ }^{24}$, nebot' jen uplatnění nároku (žalo-

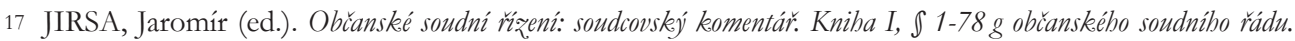
1. vyd., Praha: HBT, 2014, s. 428. ISBN 978-80-87109-39-7.

18 KUCHAŘ, Ondřej. Prétorský smír. Právní rádce. 1998, roč. 6, č. 6, s. 31. ISSN 12104817.

19 JIRSA, op. cit., s. 117.

20 Usnesení Ústavního soudu ze dne 2. června 1997, sp. zn. III. ÚS 144/97. Ústavní soud [online]. Ústavní soud 1997 [cit. 20. 3. 2016]. Dostupné z: http://nalus.usoud.cz/Search/ResultDetail. aspx?id=30093\&pos $=1 \& \mathrm{cnt}=1 \&$ typ $=$ result

21 STAVINOHOVÁ; HLAVSA, op. cit., s. 252.

22 Účinky se dělí na procesněprávní a hmotněprávní. Mezi procesní patří litispendence (t). překážka věci zahájené), perpetuatio fori, zánik žalobcova práva volit mezi více místně př́slušnými soudy a vznik povinnosti soudu věc projednat a rozhodnout. Hmotněprávním účinkem je stavení běhu promlčecích a prekluzivních lhůt. WINTEROVÁ, Alena. Civilní právo procesní. 7. vyd. Praha: Linde, 2014, s. 368-369. ISBN 978-80-7201-940-3.

$23 \int 112$ zákona č. 40/1964 Sb., občanský zákoník: „Uplatni-li věritel v promlčeci době právo u soudu nebo u jiného př̌slušného orgánu a v zahájeném ř́z̨eni rádně pokračuje nebo je-li oblednè jeho práva zahájena mediace podle zákona o mediaci, promlčeci doba neběẓ̌i od tohoto uplatnèni po dobu rízeni nebo od tohoto zabájeni po dobu mediace."

24 Usnesení Ústavního soudu ze dne 2. června 1997, sp. zn. III. ÚS 144/97. Ústavní soud [online]. Ústavní soud 1997 [cit. 20. 3. 2016]. Dostupné z: http://nalus.usoud.cz/Search/ResultDetail. aspx?id=30093\&pos=1\&cnt $=1 \&$ typ $=$ result 
bou) u soudu staví běh promlčecí lhůty ${ }^{25}$. Nový občanský zákoník (zákon č. 89/2012 Sb.,

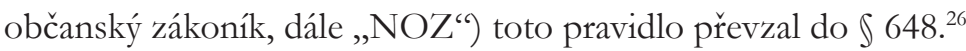

V NOZ se však objevilo nové pravidlo týkající se promlčení, které poskytuje aplikační prostor i pro účely smírčího řízení. \ 647 NOZ normuje, že ,uzavřeni dohody o mimosondnim jednáni věritele a dlữnike o právu nebo o okolnosti, která právo zakládá", má účinky stavení promlčení. Inspiraci ${ }^{27}$ čerpá ustanovení z Návrhu všeobecného referenčního rámce ${ }^{28}$ a z německé úpravy. ${ }^{29}$ Primárně jde o projev principu poctivosti a legitimního očekávání. ${ }^{30}$ Vyžaduje se shodná vůle stran jednat a „(...)učinit prèdmètem jednáni stejné určité právo nebo

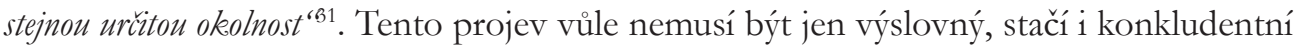
forma. Dohoda je tedy velice neformální.

Ustanovení \ 647 NOZ míŕ především na případy mediace a obdobných forem řešení sporu $^{32}$, kde je dána společná vůle stran jednat. Nabízí se možnost, že by se ustanovení dalo aplikovat také na smírčí řízení, jinak by docházelo k neproporcionálnímu zvýhodnění některých forem ADR metod vưči jiným. I smírčí řízení je totiž svým způsobem mimosoudnîi3 ${ }^{3}$, resp. mimoprocesní, jednání stran o řešení sporu. Návrh na zahájení smírčího řízení však nemusí být produktem společné vůle obou stran. Obecně tedy platí, že za úkon způsobující stavení promlčení nelze považovat zahájení smírčího (prétorského) ř́ízení. ${ }^{34}$

25 RABAN, Přemysl. Alternativní řešení sporü, arbitráž a rozhodci v České a Slovenské republice a zabraničr. 1. vyd. Praha: C. H. Beck, 2004, s. 20, 745 s. ISBN 8071798738.

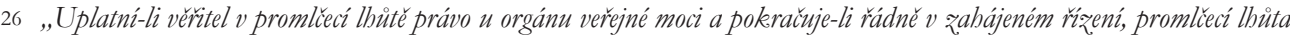
nebéžl. (...)“

27 Dle důvodové zprávy k NOZ, \647.

28 VON BAR, Christian, CLIVE, Eric, SCHULTE-NÖLKE, Hans (ed.). Principles, Definitions and Model Rule sof European Private Law: Draft Common Frame of Reference (DCFR): Outline Edition. Munich: sellier.european law publishers, 2009, s. 273.

III - 7:304: Postponement of expiry in case of negotiations - If the parties negotiate about the right, or about circumstances from which a claim relating to the right might arise, the period of prescription does not empire before one year has passed since the last communication made in the negotiations.

29 \203 BGB: Schweben zwischen dem Schuldner und dem Gläubiger Verhandlungen über den Anspruch oder die den Anspruch begründenden Umstände, so ist die Verjährung gehemmt, bis der eine oder der andere Teil die Fortsetzung der Verhandlungen verweigert. Die Verjährung tritt frühestens drei Monate nach dem Ende der Hemmung ein.

30 TÉGL, Petr, WEINHOLD, Daniel. In: MELZER, Filip, TÉGL, Petr a kol. Občanskýy zákoník - velký komentár. Svazek III. \419-654. Praha: Leges, 2014, s. 1042.

31 TÉGL, Petr, WEINHOLD, Daniel. In: MELZER, Filip; TÉGL, Petr a kol. Občanský zákonik - velký komentár. Svazek III. \ 419-654. Praha: Leges, 2014, s. 1042, 1234 s. ISBN 978-80-7502-003-1.

32 LAZÍKOVÁ, Jarmila, ŠTEVČEK, Marek. \$ 647. In: LAVICKÝ, Petr (ed.). Občanský zákonike I. Obecná cást (S 1 - 654). Komentár 1. vyd., Praha: C. H. Beck, 2014, s. 2265, 2380 s. ISBN 978-80-7400-529-9.

33 Resp. mimo sporné ř́ízení konané.

34 TÉGL, Petr, WEINHOLD, Daniel, op. cit., s. 1044. 
Pokud existuje společná vưle stran, tyto se společně obrátí na soud za účelem zahájení smírčího řízení, aplikuje se $\int 647$ NOZ a promlčení se po tuto dobu staví. Nikoliv tedy v důsledku zahájení ,pokusu o smir "před soudem, ale z titulu dřivější dohody o mimosoudním jednání.

Při podání návrhu jednou ze stran bude stavení promlčení záležet na ochotě druhé strany. Jakmile druhá strana na jednání dobrovolně přistoupí, promlčení se staví - na základě hmotněprávní dohody. Přinejmenším po dobu samotného pokusu o smír (prováděného s vưlí obou stran) promlčecí doba neběží, ačkoliv se v textu ustanovení mluví jen o „mimosoudní" dohodě.

Celé ustanovení \ 647 NOZ je ale podrobováno kritice ${ }^{35}$, zejména pro nedostatek formálních nároků na podobu dohody. Promlčecí doba znovu běží od chvíle, kdy dojde k „výslovnému“ odmítnutí jednání. Obecně může být složité prokázat, kdy došlo k výslovnému odmítnutí jednání. V procesu smírčího řízení by byl tento okamžik mnohem jednoznačnější a lépe určitelný. Jakmile se strany nedostaví ke smírčímu jednání, nebo nechtějí dále pokračovat, smírčí řízení končí - což se uvede do spisu. Smírčí řízení by tedy poskytovalo jistotu ohledně okamžiku, od kterého promlčecí doba začíná opět běžet.

Jak bylo uvedeno výše, návrh na „pokus o smír“ může přicházet od jedné strany sporu, jindy od obou (všech). Druhá možnost nastává zejména tehdy, kdy strany již mezi sebou dospěly k prrijatelnému řešení sporu, následně však chtějí prostřednictvím smírčího řízení její platnost „ověřit“, př́padně chtějí dosáhnout vykonatelnosti.

V tomto ohledu je zajímavé srovnání s rakouským právním rádem, kde je na rozdíl od České republiky výslovně vyloučeno, aby strany užívaly smírčího řízení jen jako prostředku, kterým získá jejích dohoda podoby exekučního titulu. Gramatickým výkladem české úpravy v $\int 67$ OSŘ (provedení pokusu o smír) vlastně rovněž má být ustanovení o smírčím řízení aplikováno $\mathrm{v}$ prípadech, kdy bude probíhat proces uzavírání smíru. $\mathrm{V}$ tomto ohledu je česká aplikační praxe vůči stranám vstřícnější, což lze považovat za pozitivum české úpravy.

\section{Subjekty smírčího řízení}

Co se týče samotného průběhu, účastníci mají velkou autonomii. Ve srovnání se standardním sporným řízením ${ }^{36}$ má odpovědnost účastníka ve smírčím řízení jinou kvalitu: neuplatňuje se koncentrace, ani sankce za marné uplynutí lhůt. Přesto jde v určitém ohledu o odpovědnost vyššího stupně. Účastníci předkládají podobu smíru, kterou nemůže

35 KUBOVÁ, Jana. K běhu lhůt podle občanského zákoníku. Epravo.cz [online], Epravo, publikováno 30. 10. 2014 [cit. 29. 7. 2016]. Dostupné z: http://www.epravo.cz/top/clanky/k-behu-lhut-podle-obcanskeho-zakoniku-95875.html

36 Pro sporné řízení platí princip odpovědnosti za výsledek řízení (procesní diligence). Projevem je zejm. koncentrace civilního řízení. WINTEROVÁ, Alena. Koncentrace. Bulletin advokacie. 2001, roč. 8, č. 4, s. 8. ISSN 12143758. 
formulovat sám soud. ${ }^{37} \mathrm{Na}$ nich také záleží, zda bude smírčí řízení vůbec zakončeno př́slušným soudním rozhodnutím.

Jakou roli však hraje (má hrát) ve smírčím řízení soudce? ${ }^{38}$ Má fungovat soudce jako průvodce uzavíráním smíru a regulovat jeho průběh, či se omezit jen na schvalování dohody? Někteří autoři redukují roli soudce právě jen na zkoumání, zda není dohoda vyloučena a zda smír schválit. ${ }^{39}$ Klíčová je však vždy zkušenost a osobní praxe soudce. ${ }^{40}$ Potenciální zájemci se někdy mohou domnívat, že soud není „(...)vąhledem ke své obvyklé rozhodovací činnosti divvéryhodným orgánem ke urovnáni sporu“41, ani že není „na smirč́ jednání odborněprĭpraven " 42

Otázky ohledně zachování smírčího řízení se nabízejí v souvislosti s plánovanou rekodifikací civilního řízení. Někteří považují za optimální řešení „,...vyvedení určitých agend mimo soudy, k.dy by byly v tžv. prunim kole réšeny mimosoudnimi orgány, to povede k odbremenéni soudü. "43 Právě odbřemenění soudů je argumentem proti provádění smírčího řízení soudy. Předseda rekodifikační komise Roman Fiala zastává názor, že fáze řešení sporu smírně nemajî zatěžovat soudce, ale mají být „svěreny níže postaveným pracovnikeim soudů a mediátorìm. Úkolem soudcu má být výhradně projednáni př̆padu a jeho rozhodnutí. "*4

Výše uvedené př́istupy vedou $\mathrm{k}$ několika variantám řešení:

a) Smírčí řízení zůstane v právní úpravě civilního procesu. Nadále jej budou vést soudci. Zvýšené nároky na osobu smírčího soudce povedou k vyčlenění soudce (soudců), kterým by byly přednostně přidělované návrhy na smírčí řízení. Podobné úvahy panují také v Rakousku. Vzhledem ke statistikám ${ }^{45}$ počtu uzavírání smíru

37 BAJCURA, Andrej, MOLČAN, Teodor. K povahe procesného úkonu podl'a \99 ods. 3 Občianskeho

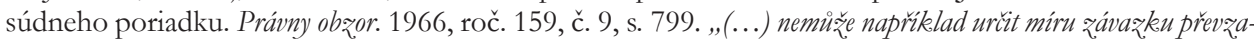
tého soudním smirem (...)“"

38 PEJCHAL, Aleš. Civilní proces jako nástroj nalézání a tvorby práva. Bulletin advokacie. 2005, roč. 12, č. 10, s. 11. ISSN 12143758.

39 SVOBODA, Karel. Na co si dát pozor při uzavírání smíru. Jurisprudence. 2007, roč. 16, č. 5, s. 19. ISSN 12129909.

40 KRÁLÍK, Michal. K možnosti vyloučení soudce z projednávání a rozhodnutí věci v souvislosti s jeho snahou o dosažení smíru mezi účastníky v probíhajícím soudním řízení. Soudni roz̧bledy. 2007, roč. 13, č. 2, s. 61. ISSN 12106410.

41 BĚHOUNEK, Tomáš. Mediace v civilním řízení. Právní roz̧hledy. 2004, roč. 12, č. 19, s. 714. ISSN 12106410.

42 Tamtéž.

43 Názor Tomáše Novosada, viceprezidenta Soudcovské unie, prezentovaný na konferenci „Zvýšení efektivity soudnictví - alternativní řešení sporů v České republice“. Viz 94130. ADR - konečné řešení? Epravo. cz. [online]. eFocus, publikováno 16. 4. 2014 [cit. 25. 7. 2016]. Dostupné z: http://www.epravo.cz/top/ efocus/adr-konecne-reseni-94130.html

44 FIALA, Roman. Na cestě k novému civilnímu procesnímu právu. Epravo.cz [online]. eFocus, publikováno 12. 3. 2015 [cit. 1. 8. 2016]. Dostupné z: http://www.epravo.cz/top/efocus/na-ceste-k-novem-civilnimu-procesnimu-pravu-97264.html

45 MYSLIL, op. cit., s. 30. 
v České republice by nebyla jejich zvláštní „,specializace“ překážkou pro výkon běžné judikatorní činnosti, ale zaručila by řádný průběh smírčího řízení.

b) Smírči řízení bude upraveno v kodexu civilního procesu, ale bude svěřeno namísto soudců níže postaveným pracovníkům (tj. vyšším soudním úředníkům), př́ípadně mediátorům. Mediátoři by smírčí řízení prováděli u soudu.

c) Odstranit úpravu smírčího řízení z občanského soudního řádu. I zde přicházejí v úvahu dva př́stupy:

- Vytvořit speciální smírčí orgány, které by prováděly pokus o smír - pravděpodobně ve vybrané agendě. Tato možnost existovala již za doby první republiky. Ve věcech peněžních a bankovních byl zaveden obligatorní pokus o smír. Probíhal před zvláštním smírčím orgánem. ${ }^{46}$ Před pokusem o smír nebylo možné uplatnit nárok soudně. Aby měly strany vưli obracet se na tento orgán, dnem, kdy došla věc na smírčí orgán, se stavěly lhůty i promlčení (『 50 odst. 4 z. č. 111/1927 Sb., zákon o ochraně proti nekalé soutěži). Jak však uvádí prof. Hora, „nemá smír, byl-li zjednán, moc smiru soudního ". ${ }^{47}$ Stejně tak by smír dosažený speciálním smírčím orgánem nenabýval účinků pravomocného rozsudku. Vykonatelnosti by muselo být dosahováno samostatným postupem (či řízením).

- Nebo ponechat smírné řešení výlučně na jiných ADR metodách, zejména na mediaci, př́padně dosáhnout dohody mezi stranami s pomocí notáře. U mediace je však nutné upozornit na to, že výsledná dohoda (smírné řešení sporu) není automatickým exekučním titulem. Stále by tedy bylo nutné vytvořit mechanismus, jak ,„proměnit““ mediační dohodu v exekuční titul. ${ }^{48}$

Je dobré se zmínit také o tom, že smír neprobíhá při jednání dle $\int 115$ OSŘ, ale při smirčim jednání. To je analogii tzv. jiného soudního roku ${ }^{49}$ - operativní alternativy běžného jednání. Jiný soudní rok se sice vyznačuje neveřejností, ale v př́ípadě smírčího řízení není důvěrnost výslovně stanovena (na rozdíl např̀. od mediace). V průběhu řízení je možné také dokazování, ačkoliv není zásadně potřebné jej provést v rozsahu sporného řízení. ${ }^{50}$ V rakouském právním řádu se odkazuje v otázce dokazování - podle mého názoru velmi vhodně - na ustanovení o zajištění důkazu ${ }^{51}$ (\384 Zivilprozessordnung, dále jen ZPO). To vystihuje pojetí smírčího řízení coby předběžného řízení a mohlo by být využito také v českém civilním procesu.

46 『 49 a 50 z. č. 111/1927 Sb., zákona na ochranu proti nekalé soutěži.

47 HORA, 1947, op. cit., s. 421.

48 Což v současnosti nabízí právě $\int 67$ odst. 2 OSŘ - schválení mediační dohody.

49 『 18 zákona č. 292/2013 Sb., zákona o zvláštních řízeních soudních.

50 DRÁPAL, Ljubomír. In: BUREŠ, Jaroslav, DRÁPAL, Ljubomír, KRČMÁř, Zdeněk (ed.). Občanský sondní rád-komentár - I. díl. 7. vyd., Praha: C. H. Beck, 2006, s. 644, 2120 s. ISBN 80-7179-378-7. Účastníci při něm ani nenesou důkazní břemena.

51 MAYR. Der gericthliche..., s. 126. 
O schválení či neschválení smíru se rozhoduje usnesením, pravděpodobně z důvodu jeho operativnosti. ${ }^{52}$ Usnesení, jímž smír schválen není, není meritorním rozhodnutím. ${ }^{53}$ Avšak usnesení, které smír schvaluje, je typem „věcného vyrè̌ení sporu“.54 Je závazné jak pro účastníky, tak pro (všechny) státní orgány.

\section{Smírčí řízení jako ADR forma}

Co se týče metody postupu při dosahování smíru (smírného řešení stran), podobá se smírčí řízení v mnohém mediaci (dobrovolnost ${ }^{55}$, nezávazný charakter ${ }^{56}$, princip sebeurčení stran ${ }^{57}$ apod.). Největší rozdíly spočívají v tom, že mediátor „nemá žádnou jurisdikěni pravomoc" ${ }^{58}$ A soudce v průběhu smírčího řízení spíše „neformálně využivá vhodných prostredkü, kterými se snaži smíru dosábnout ${ }^{\text {ra9 }}$, protože jeho primární rolí není zprostředkovávání komunikace mezi stranami. ${ }^{60}$ Domnívám se, že stále panuje větší „důvěra“

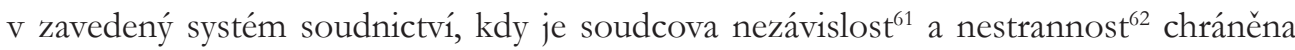
podstatně více. $\mathrm{Na}$ druhou stranu se však prostor civilního procesu postupně otevírá jiným metodám řešení a také široká veřejnost získává větší povědomí o ADR metodách. Zvláštní otázkou je důvěrnost procesu. Tím se myslí jeho neveřejnost ${ }^{63}$, která je základním atributem mediace (ačkoliv dobrovolným). Mediaci nejsou bez výslovného souhlasu stran účastny žádné další osoby. Ani při smírčím řízení se nevede soudní jednání ${ }^{64}$ ve smyslu \115 OSŘ, výslovný zákaz veřejnosti však neexistuje. To by mohlo strany sporu od využití smírčího řízení odrazovat.

52 Důvodem pro schvalování formou usnesení je zachování hospodárnosti a rychlosti řízení. SCHELLEOVÁ, Ilona. Ceský civilní proces: vysokoškolská právnická učebnice. Praha: Linde, 1997, 728 s., s. 604. ISBN 8072010654.

53 HRDLIČKA, Jindřich. Žaloba o neplatnost smíru. Socialistická zákonnost. 1966, roč. 14, č. 3, s. 140. Dohoda jako smlouva může právně existovat, přestože soud rozhodl (nesprávně) o neschválení smíru.

54 KNOBLOCHOVÁ, Věra. Alternativní způsob řešení sporů: Porovnání soudního smíru a mediace. Právník. 2000, roč. 139, č. 9, s. 859. ISSN 03247007. „U prétorskébo smíru nelze hovorit o procesním sporu. “

55 POTOČKOVÁ, Dana. Nejlepší je domluvit se, aneb, Privodce mediačním procesem. 1. vyd. Praha: Alfom, 2013, s. 56, 197 s. ISBN 978-80-87785-00-3.

56 RABAN, op. cit., s. 9.

57 HORÁČEK, Tomáš. Základní principy mediace (z právního i neprávního pohledu). Bulletin advokacie. 2013, roč. 20, č. 6, s. 21. ISSN 12143758.

58 DOLEŽALOVÁ, VAN LEYNSEELE. Mediace v..., s. 420.

59 STAVINOHOVÁ, HLAVSA. Civilní proces..., s. 252.

60 Zprostředkování komunikace je hlavním atributem role mediátora. In: ŠTANDERA, Jan. Mediace možná cesta z labyrintu soudního řízení? Právní roz̧bledy, 2011, roč. 19, č. 22, s. 803-810.

61 Nezávislost soudců zabezpečuje stát (\$ 75 odst. 1 ZSS).

62 ŠTAJGR, František. Zásady civilního soudního ř́zení. 1. vyd., Praha: Všehrd, 1946, s. 10.

63 BĚHOUNEK. Mediace v..., s. 713.

64 ŠKÁROVÁ. Ob̌́anský soudní rád..., s. 125. Jde o tzv. jiný soudní rok. 
U mediace výsledkem není exekuční titul ${ }^{65}$, ale pouhá hmotněprávní smlouva, kterou se odklízí spor. ${ }^{66}$ Požadavek směrnice EU o mediaci zajistit „...) aby byl obsah pisemné dohody vyplývající z. mediace učnèn vykonatelným '67 český zákonodárce vyřrešil tak, že využil existující institut smírčího rúzeníi ${ }^{68}$ a vložil do ustanovení \ 67 OSŘ nový odst. 2: „Sond rozhodne o tom, zda schvaluje mediačni dohodu uzavrenou podle zákona o mediaci, nejdéle do 30 dnu od zahájeni smirč́ho rízeni."

Postup je to racionální a může vést ke zvýšenému zájmu o smírčí řízení obecně. Nejedná se však o smírčí řízení v pravém slova smyslu, odpadá totiž fáze samotného pokusu o smír, soud se omezí na rozhodnutí o schválení dohody. Není však vyloučeno, aby soud (zejm. $\mathrm{v}$ prípadě nejasností) obeslal strany k jinému soudnímu roku.

Ne zcela obvyklým je řešení, kdy je pro rozhodování soudu stanovena lhůta (30 dnů). Snad panovala obava, že strany obeznámené s běžnou délkou soudního řízení, se budou zdráhat využít této možnosti. Lhůta je však svou povahou pořádková a s jejím uplynutím není spojen žádný prímý právní účinek. Má tedy spíše efekt psychologický.

Notářský zápis se svolením k vykonatelnosti může být rovněž vnímán jako alternativa smírčího ř́zení, nebot' jeho výsledkem je taktéž exekuční titul ${ }^{69}$, který „,nabrazuje rozsudek soudu“"70 Poskytuje podobné záruky, vždyt' notář - stejně jako soudce ve smírčím řízení - musí uplatňovat zásadu nestrannosti (i v oblasti manudukční povinnosti) a je povinen odmítnout sepsat zápis, pokud by ujednání stran mělo odporovat obecně závazným předpisům. ${ }^{71}$

Tento „préedem dohodnutý smir" poté umožňuje věriteli vymáhat jeho obsah, „aniž by k tomu musel mit rozhodnutí soudu o schválení smíru (...) “72

Výhodou smírčího řízení oproti notářskému zápisu je však nižší finanční nákladnost. Za zahájení smírčího řízení se poplatek neplatí a poplatková povinnost vzniká až schválením dohody v podobě smíru. ${ }^{73}$ Za notářský zápis je nutné zaplatit nejen odměnu no-

65 HÁJKOVÁ, Šárka. Mediace v kontextu občanského soudního řízení. Bulletin advokacie. 2013, roč. 20, č. 6, s. 25. ISSN 12143758. Lze získat vykonatelnost schválením soudem, a to bud' v rámci smírčího řízení v podobě prétorského smíru, či v již zahájeném soudním řízení ve formě soudního smíru.

66 HÁJKOVÁ, Šárka. In: DOLEŽALOVÁ, Martina (ed.). Zákon o mediaci. Komentár. 1. vyd. Praha: C. H. Beck, 2013, 345 s., s. 37. ISBN 978-80-7400-458-2.

67 Směrnice Evropského parlamentu a Rady č. 2008/52/ES ze dne 21. května 2008, o některých aspektech mediace v občanských a obchodních věcech. Úř. věst. L 136, 24. května 2008, s. 3-8. Článek 6: Vykonatelnost dohod vyplývajících z mediace.

68 DOLEŽAlovÁ, Martina. In: DOLEŽAlOVÁ, Martina (ed.). Zákon o mediaci..., s. 142. ISBN 978-80-7400-458-2.

69 Usnesení NS ze dne 22. července 2004, sp. zn. 20 Cdo 928/2003.

70 JINDŘICH, Miloslav. In: BÍLEK, Petr (ed.). Notárský rád a ř́zení o dédictví komentár. 4. vyd., Praha: C. H. Beck, 2010, s. 268.

$71 \int 53$ odst. 1 NŘ.

72 JINDŘICH, Miloslav. In: BÍLEK (ed.). Notárské rád..., s. 267.

73 Viz ZOSOP - bod 2 položky 9 Sazebníku soudních poplatků. 
táře za notářskou činnost (tarifní hodnota), ale notář má nárok i na náhradu hotových výdajů. ${ }^{74}$

Pro úplnost je třeba doplnit, že smírčí řízení je upraveno také v \ 24 zákona č. 216/1994 Sb., zákon o rozhodčím řízení a o výkonu rozhodčích nálezu (zkráceně ZRŘ). Pokud se smír stane součástí rozhodčího nálezu, nabývá taktéž charakteru exekučního titulu.

\section{Rakouská právní úprava}

Rakouská úprava smírčího řízení je velmi vhodná pro komparaci s českým prostředím. Obecně vykazuje podobné rysy: je upraveno v \433 Zivilprozessordnung ${ }^{75}$ (ZPO), který u nás platil do roku 1950. Ve velké míře se tu však projevuje právní kontinuita a dlouhý vývoj právní nauky. Statistiky navíc ukazují, že smírčí řízení v Rakousku je využíváno podstatně více. Např́íklad v roce 1999 bylo uzavřeno celkem 6796 prétorských smírů. ${ }^{76}$ Na druhou stranu i zde je patrné, že „obliba“ smírčího řízení klesá, v roce 2000 už to bylo jen přibližně $5000 .^{77}$

Úprava je podobně strohá. Na rozdíl od ČR je (formálně) možné provést smírčí řízení jen v př́padě, že strana již zamýšlí vznést žalobu. ${ }^{78}$ Pouze takový subjekt by měl být oprávněn k podání návrhu na zahájení smírčího řízení. Naopak \67 OSŘ žádný požadavek „úmyslu žalovat“ výslovně neklade. To podtrhuje skutečný význam smírčího řízení, kterým je samotný pokus o smír.

Soud není povinen, ani oprávněn, mezi stranami mimosoudně dosaženou dohodu jen potvrzovat. ${ }^{79}$ Platí jediná výjimka, a to \433a ZPO (tzv. Prätorischer Mediationsvergleich). Stejně jako v České republice se díky tomuto ustanovení smírčí řízení napříště využívá také k získání vykonatelnosti mediační dohody. ${ }^{80}$

Rakouská odborná literatura se zabývá v tomto ohledu i otázkou, zda lze prostřednictvím smíru obsah mediační dohody pozměnit. Okrajové aspekty zřejmě lze v souladu

74 Odměnu za výkon činnosti notáře stanovuje vyhláška č. 196/2001 Sb., o odměnách a náhradách notářŭ, správců pozůstalosti a Notářské komory České republiky (notářský tarif), ve znění pozděǰších předpisů.

75 Zákon RGBl. Nr. 113/1895, Zivilprozessordnung (rakouský občanský soudní řád).

76 MAYR, Peter. Der gerichtliche Vergleichsversuch. Wien: Verlag Österreich, 2002, s. 109.

77 MAYR, Peter. Der gerichtliche Vergleichsversuch. Wien: Verlag Österreich, 2002, s. 109.

78 RECHBERGER, SIMOTTA. Grundriss des..., s. 10.

79 \547 GEO: „Vergleiche nach \433 ZPO: \433 ZPO verfolgt den Zweck, streitige Rechtsverhältnisse in einfachster Weise zu bereinigen. Hingegen sind die Gerichte weder verpflichtet noch berechtigt, zwischen den Parteien außergerichtlich zustande gekommene Vereinbarungen zu beurkunden und vollstreckbar zu machen. Diesem Zwecke hat vielmehr die Einrichtung des vollstreckbaren Notariatsaktes $(\mathbb{} 3$ $\mathrm{NO}$ ) zu dienen."

80 FRAUENBERGER-PFEILER, Ulrike, RISAK, Martin. Der Prätorische Mediationsvergleich. Österreichische Juristen-Zeitung. 2008, roč. 67, č. 18, s. 799. 
s konsensem stran pozměnit či doplnit. ${ }^{81}$ Tento závěr je přijatelný také v poměrech českého právního řádu.

Směrnice předpokládá, že „stačí podat návrh jednou stranou s výslovným souhlasem druhé،, rakouská varianta prétorského smíru žádnou takovou podmínkou neurčuje, což je vnímáno jako vada implementace. ${ }^{82}$ Ani česká transpozice však nezmiňuje, že by byl návrh na schválení mediační dohody podmíněn souhlasem obou stran.

Rakouský soud nemá povinnost ex offo hledět k tomu, že byl smírem odklizen spor zabývá se jím pouze $\mathrm{v}$ prrípadě vznesení námitky rei transacta. ${ }^{83}$ Z toho plyne, že rakouská úprava se drží římskoprávního pojetí prétorského smíru. Považuje jej nikoliv za překážku procesního charakteru, ale za hmotněprávní obranu. To klade vyšší nároky na znalosti účastníků řízení, nebot' jen jejich aktivita vede k zamítnutí žaloby pro překážku sjednaného smíru. Český právní řád je v tomto ohledu vůči účastníkům přivětivější, dokonce se v některých úvahách o budoucnosti smíru v Rakousku mluví o zavedení účinku res indicata.

Z povahy smíru jako hmotněprávní dohody plyne, že je možné uzavřít smír s podmínkou. Zatímco české právnické učebnice civilního procesu o této možnosti většinou mlčí, přichází v úvahu nejen v rakouském smírčím řízení, ale také u nás. V Rakousku může jít pouze o podmínku odkládací, nikoliv rozvazovací. ${ }^{84}$ Takto např. lze stanovit určitou lhůtu pro př́padné odvolání, jejímž marným uplynutím se stává smír účinným. ${ }^{85}$

Nejviditelnější rozdíly se objevují v př́stupu k řešení vad smíru. Do českého právního řádu byl zaveden speciální prostředek, tzv. žaloba na neplatnost smíru dle $\int 99$ OSŘ. V Rakousku neexistuje žádná obdoba tohoto institutu. Př́i vadách se postupuje v souladu s teorií „Doppeltatbestand“. Ta posuzuje hmotněprávní a procesněprávní předpoklady smíru nezávisle na sobě.

Hmotněprávní vady se řeši dle ustanovení občanského práva hmotného, a to novým samostatným soudním řízením, zahájeným zápornou určovací žalobou (na neúčinnost smíru). ${ }^{86}$ Nelze uplatnit návrh na pokračování původního smírčího řízení. ${ }^{87}$ Někteří au-

81 Tamtéž.

82 Tamtéž, s. 800.

83 HORA, Václav. Československé civilní právo procesní, díl II. 2. vyd. Praha: nákladem vlastním, 1928, s. 420.

84 Rozhodnutí OGH ze dne 6. záři 1967, sp. zn. 6 Ob 229/67: „Der gerichtliche Vergleich hat zugleich den Charakter eines zivilrrechtlichen Vertrages und einer Prozesshandlung. Er kann nicht resolutiv, wohl aber suspensiv bedingt abgeschlossen werden. "

85 Rozhodnutí OGH ze dne 15. října 1986, sp. zn. 3 Ob 600/86: „Weil Vergleiche, die unter der aufschiebenden Bedingung des Nichtwiderrufs während bestimmter Frist geschlossen werden, erst mit dem ungenützten Ablauf der Widerrufsfrist wirksam werden, tritt auch ibre allfällige prozessbeendende Wirkung erst in diesem Zeitpunkt."

86 Rozhodnutí OGH, sp. zn. 19594 Ob: „Zulässigkeit einer Klage auf Feststellung des wabren Inhaltes eines gerichtlichen Vergleiches. "

87 ATTESLANDER-DÜRRENMATT. Der Prozessvergleich im..., s. 70. 
toři ${ }^{88}$ se přimlouvají za zavedení žaloby na neplatnost smíru, jakou zná české právo. Pak by bylo zajímavé sledovat, jakou formu a znění by rakouská legislativa zvolila.

Výzvou pro českou právní úpravu může být obligatorní smírčí rrízení. Do rakouského práva byl zaveden povinný pokus o smírné řešení sousedských sporů v otázce odepření světla nebo vzduchu kvưli cizím stromům nebo rostlinstvu (\ 364 odst. 3 Článek III $\left.\mathrm{ABGB}^{89}\right)$. Strany mohou zvolit smírčí řízení, či předložit spor mediátorovi. ${ }^{90}$ Prokázání pokusu o smír je procesním předpokladem pro podání žaloby ve věci. Žaloba je př́pustná, i pokud není dosaženo dohody do 3 měsíců od zahájení pokusu. Obligatorní pokus o smír (či dohodu) je jednou z forem, jak přiblížit veřejnosti institut smírčího řízení (resp. mediace).

\section{Závěr}

Smírčí řízení má v českém právu dlouhou historii. To však automaticky neznamená, že se těší velké oblibě. Důvodů může být více: neochota pokoušet se o smír (a raději přejít rovnou ke spornému řízenî), nedůvěra $\mathrm{v}$ institut, ale především neznalost této možnosti.

V současnosti se nabízejí další ADR metody, které částečně konkurují smírčímu řízení. Vycházejí ze zásady, že smírné řešení sporů je vhodnější ponechat na „mimosoudních“ mechanismech, bez zásahů a účasti soudů. Č́st typicky soudní agendy se tak stává více soukromou, spojenou s neformálností (a nesvázaností pravidly).

Předností prétorského smíru je to, že v sobě spojuje prvky hmotného a procesního práva. Tím, že mu byly v české právní úpravě přiznány účinky res indicata, funguje také jako exekuční titul. Výhodou jsou i nižší náklady této metody řešení sporu vưči jiným (sporné řízení, notářský zápis aj.). Pokud smíru dosaženo není, neplatí se za řízení žádný soudní poplatek. ${ }^{91}$ Výhodou může být i zaštítění procesu státem poskytujícím garance nezávislosti a nestrannosti ř́zení.

Problematickým se jeví nedostatek účinků spojených s podáním žaloby (např. se nestaví promlčenî) a přetíženost soudců, kteří by si navíc museli osvojit další znalosti a dovednosti. Je však nutné vnímat smírčí řízení jako efektivní prostředek smírného řešení sporů. Domnívám se, že tudíž není namístě institut zcela opustit.

88 Např. KLICKA, Thomas. In: KLICKA, Thomas. Auserstreitverfahren. Wien: Manz, 2014, 135 s.

89 Zákon JGS Nr. 946/1811, Allgemeiner bürgerliches Gesetzbuch (rakouský občanský zákoník), ve znění zákona BGBl. 1 Nr. 35/2015: tzv. „,außergerichtliche Streitbeilegung“ (mimosoudní urovnání sporu).

90 Žalobce poté připojí k žalobě potvrzení daného orgánu o tom, že spor nelze smírně urovnat.

91 Př́loha zákona č. 549/1991 Sb., o soudních poplatcích, ve znění pozdějších předpisů, položka 9. Bod č. 3 . 